\title{
Efficacy of Fungicides in Control of Fusarium oxysporum f. sp. dianthi, the Cause of Wilt in Carnation
}

\author{
B.G. Manasa ${ }^{1}$, Y.M. Somashekara ${ }^{1}$, K. Shankara ${ }^{2 *}$ and Chikkanna Swamy ${ }^{2}$ \\ ${ }^{1}$ Department of Plant Pathology, ${ }^{2}$ Department of Plant Pathology, UAS, Raichur, \\ Karnataka, India \\ *Corresponding author
}

\section{A B S T R A C T}

\begin{tabular}{|l|}
\hline Ke y w o r d s \\
Carnation, \\
$\begin{array}{l}\text { Fusarium wilt, } \\
\text { Fusarium } \\
\text { oxysporum f. sp. } \\
\text { dianthi, Fungicides. }\end{array}$ \\
\hline Article Info \\
\hline $\begin{array}{l}\text { Accepted: } \\
\text { 21 September } 2017 \\
\text { Available Online: } \\
\text { 10 October } 2017\end{array}$ \\
\hline
\end{tabular}

Keywords

Carnation,

Fusarium wilt,

Fusarium

oxysporum f. sp.

Article Info

Accepted:

21 September 201

10 October 2017
The fungus that causes wilt of carnations is Fusarium oxysporum f. sp. dianthi, specific only to carnations and closely related plants. In our study, six fungicides were selected and tested their efficacy in reducing the Fusarial population and wilt incidence. The fungicides were applied to the soil by drenching method. Fusarium population was recorded at before the application of fungicides and every 15 days interval upto $45^{\text {th }}$ day after application. Among all the tested fungicides, propiconazole @ 0.1 per cent $\left(1.66 \times 10^{3} \mathrm{cfu}\right.$ per gram of soil and $9.33 \%$ wilt incidence) followed by carbendazim @0.2 per cent $\left(2.66 \times 10^{3}\right.$ cfu per gram of soil and $11.19 \%$ wilt incidence) were significantly found effective in reduction of soil population of Fusarium and wilt incidence in polyhouse condition.

\section{Introduction}

Carnation (Dianthus caryophyllus L.) is one of the most important commercially grown flowers of the world. It is native to Mediterranean region. It belongs to family caryophyllaceae. It is popular as cut flower on account of its exquisite shape, wide range of colours, good vase life and light in weight which makes it ideal for distant markets. In Karnataka, Carnation is grown under 19 units with a production of 338 lakh tons cut flowers per annum, valuing 1029 lakh rupees, as per 2002-03 estimates (Anon., 2004).

The average yield level per hectare in Karnataka is very low; many factors may be attributed for the low yields, of which one of the important factors may be poor management of pests and diseases.

A number of biotic stresses such as, the fungal diseases are fusarium wilt (Fusarium oxysporum f.sp. dianthi), bud rot (Rhizoctonia solani), rust (Uromyces dianthi), Grey mould (Botrytis cinerea), Stem and root rot (Phytophthora spp.), fairy ring spot (Heterosporium edinulatum), bacterial wilt (Pseudomonas caryophylli), southern blight (Sclerotium rolfsii). The Root knot nematode (Meloidogyne incognita) disease associated with carnation are predominant in India 
(Nagesh et al., 2001). Among all the pathogen, Fusarium wilt (Fusarium oxysporum f. sp. dianthi) is one of the major constraints worldwide in carnation (Dianthus caryophyllus Linn.) cultivation in greenhouse and field plantations.

The fungus is soil inhabitant and has the potential ability to cause significant yield reduction and loss in flower quality (Jacob and Krebs, 1985). The planting is done through cuttings and therefore the plant becomes more susceptible to this disease. Wilting occurs on the affected side of the plant, followed by vascular discolouration and stem necrosis.

\section{Materials and Methods}

\section{In vivo evaluation of fungicides}

Field experiment was conducted in a farmer field at Yelachagere, Nelamangala Taluk, and Bengaluru district. The carnations wilt pathogen, Fusarium oxysporum f.sp. dianthi, the fungicide propiconazole $(0.1 \%)$ difenconazole $(0.1 \%)$, carbendazim $(0.2 \%)$, captan $(0.2 \%)$ benomyl $(0.2 \%)$ and chlorothalonil $(0.1 \%)$ were drenched to the Fusarium infected plants. The soil drenching of fungicides was done in different application. Each chemical drenched in following ways.

\section{Details of the treatments imposed}

\section{Soil drenching of fungicides (One application)}

T1 - Propiconazole @ 0.1\% one application, T2 - Difenconazole @0.1\% one application, T3 - Carbendazim @ 0.2\% one application, T4 - Captan@0.2\% one application, T5 Benomyl @ 0.2\% one application, T6 Chlorothalonil @0.1\% one application, T7 Control without any fungicide.
Soil drenching of fungicides (Two applications)

T1 - Propiconazole @ 0.1\% two application, T2 - Difenconazole@ 0.1\% two application, T3 - Carbendazim @0.2\% two application, T4 - Captan@ $0.2 \%$ two application, T5 Benomyl @0.2\% two application, T6 Chlorothalonil@0.1\% two application, T7 Control without any fungicide.

Soil drenching of fungicides (Three applications)

T1 - Propiconazole@ 0.1\% three application, T2 - Difenconazole@ 0.1\% three application, T3 - Carbendazim @ 0.2\% three application, T4 - Captan@0.2\% three application, T5 Benomyl@0.2\% three application, T6 Chlorothalonil @ 0.1\% three application, T7 Control without any fungicide.

The untreated beds were kept for comparison by without fungicide applications. Each treatment was replicated three times. The carnation variety was used in this experiments was Indios and soil type was red sandy loam. The design used for experiment was RCBD. Before soil application of fungicides, the Fusarium population was worked out by using PCNB agar medium. The soil samples were collected with an interval of 15 days and population of fusarium was worked out by using PCNB agar medium and the wilt incidence also recorded in one square meter area and data converted in to per cent wilt incidence.

The fusarial population count, 10 grams of soil sample collected in each fungicides treated plots and poured to $90 \mathrm{ml}$ water blank and shacked for 30minutes. After $1 \mathrm{ml}$ of supernatant collected and poured to $90 \mathrm{ml}$ water blank. Similarly serial dilution was made up to $10^{6}$. The one ml of dilution of $10^{3}$ was poured on to sterilized petriplates. And 
then $15 \mathrm{ml}$ of specific peptone PCNB agar medium was poured in to the petriplates. The petriplates were shacked clock wise and anticlock wise direction and the plates were incubated at room temperature for one week and further development of fusarial colonies on specific media were recorded.

\section{Results and Discussion}

\section{Field evaluation of fungicides}

The Fusarial population was reduced from 24 to $4 \times 10^{3}$ cfu per gram of soil, in the propiconazole applied soil. The same fungicide drenched twice and thrice on 15 and 30 days interval were recorded 3 and $1.66 \mathrm{x}$ $10^{3} \mathrm{cfu}$ per gram of soil respectively (Tables 1, 2 and 3 ).

The fungicide difenconazole showed the soil population $5.0,8.3$ and $7.33 \times 10^{3} \mathrm{cfu}$ per gram of soil in the fungicide applied once, twice and thrice respectively. Similar results were obtained by Nel et al., (2007) reported that the DMI fungicides, prochloraz, propiconazole significantly reduced the incidence of Fusarium oxysporum f.sp. cubense with the root dip and soil drench treatments one week after planting up to 80.6per cent. The fungicide benomyl recorded the least soil population of Fusarium viz., 2.33, 3.66 and $7.0 \times 10^{3} \mathrm{cfu} / \mathrm{g}$, when the fungicide applied once, twice and thrice respectively.

The three time application of carbendazim reduced the soil population from 23.00 to 2.66 $\mathrm{x} 10^{3} \mathrm{cfu}$ per gram of soil. The results are comparable with Pratibha Sharma (2000) who found that carbendazim at 0.2 per cent was the best treatment amongst the fungicides tested against carnation wilt. Sunita and Katoch (2001) also reported that under field conditions carbendazim and benomyl reduced the carnation wilt incidence up to 80 per cent.

\section{Effect of soil drenching on wilt incidence}

The fungicide carbendazim reduced wilt incidence from 23.20 to 11.19 per cent in single application. The fungicides applied twice and thrice the wilt incidence significantly reduced to 5.00 and 0.00 per cent respectively. The carbendazim also inhibited the fungal growth of carnation wilt pathogen Fusarium oxysporum f.sp. dianthi in vitro condition and also the same fungicide drenched for three application reduced fusarial population in soil with wilt incidence. Similar observations have been made by Javed et al., (1997), who achieved best control of Fusarium solani infection in onion by carbendazim in vitro and in vivo. Suppression of root colonisation of mung bean by Fusarium spp. (Shahzad, 1994).

Bavistin showed maximum inhibition of mycelium of Fusarium solani under in vitro conditions while under field conditions gave the lowest root rot incidence of Acacia catechu (Tomar, 2004). The results are comparable with Pratibha Sharma (2000) who found that carbendazim at 0.2 per cent was the best treatment amongst the fungicides tested against carnation wilt. Kapoor and Kumar (1991), Rathnamma (1994), Gopinatha et al., (2006), Narendrappa and Jayarame Gowda (1995), Ghosh and Sinha (1981).

The wilt incidence reduced from 21 to 9.33 per cent in single application of propiconazole. In second and third application the wilt incidence was recorded 5.28 and 4.88 per cent respectively. Earlier reports suggested that the efficacy of propiconazole for disease control in several crop plants against various diseases. Propiconazole spray significantly reduced anthracnose of strawberry (Smith and Black, 1991), grey leaf spot of maize (Munkvold et al., 2001) and fungal leaf spots of rye grass (Koelsch et al., 1995). 
Table.1 Management of carnation wilt by soil drenching with fungicides (One application)

\begin{tabular}{|c|c|c|c|c|c|c|c|}
\hline \multirow[b]{2}{*}{$\begin{array}{l}\text { Sl. } \\
\text { No. }\end{array}$} & \multirow[b]{2}{*}{ Treatments } & \multicolumn{4}{|c|}{ Fusarial population $\left(\mathrm{cfu} / \mathrm{g}\right.$ of soil $\left.\times 10^{3}\right)$} & \multicolumn{2}{|c|}{ Per cent wilt incidence } \\
\hline & & $\begin{array}{c}\text { Zero day } \\
\text { (Before application) }\end{array}$ & $\begin{array}{l}15^{\text {th }} \text { day after } \\
\text { application }\end{array}$ & $\begin{array}{l}30^{\text {th }} \text { day after } \\
\text { application }\end{array}$ & $\begin{array}{l}45^{\text {th }} \text { day after } \\
\text { application }\end{array}$ & $\begin{array}{c}\text { Before } \\
\text { application }\end{array}$ & $\begin{array}{c}45^{\text {th }} \text { day after } \\
\text { application }\end{array}$ \\
\hline 1. & Propiconazole@0.1\% & 24.00 & 14.00 & 13.00 & 4.00 & $21.00(27.20)^{*}$ & $9.30(17.70)$ \\
\hline 2. & Difenconazole@0.1\% & 22.00 & 17.00 & 11.30 & 5.00 & $24.60(29.70)$ & $11.00(19.30)$ \\
\hline 3. & Carbendazim@0.2\% & 42.30 & 15.00 & 7.60 & 4.30 & $23.20(28.70)$ & $11.10(19.50)$ \\
\hline 4. & Captan@0.2\% & 41.00 & 32.00 & 16.60 & 10.60 & $19.90(26.50)$ & $12.30(20.50)$ \\
\hline 5. & Benomyl @ 0.2\% & 23.00 & 14.60 & 16.30 & 2.30 & $25.40(30.20)$ & $15.50(23.10)$ \\
\hline 6. & Chlorothalonil @ 0.1\% & 22.00 & 19.00 & 7.30 & 5.30 & $26.10(30.70)$ & $22.30(28.10)$ \\
\hline 7. & Untreated check & 24.00 & 25.30 & 27.30 & 26.30 & $27.10(31.40)$ & $28.00(31.90)$ \\
\hline \multicolumn{2}{|c|}{ S.Em \pm} & & 0.78 & 0.66 & 0.49 & 0.77 & 0.75 \\
\hline \multicolumn{2}{|c|}{ CD@ $5 \%$ level } & & 2.41 & 2.04 & 1.52 & 2.38 & 2.32 \\
\hline \multicolumn{2}{|c|}{$\mathrm{CV} \%$} & & 6.94 & 8.08 & 10.31 & 5.60 & 8.34 \\
\hline
\end{tabular}

*Figures in the parenthesis are arc sine transformed values

Table.2 Management of carnation wilt by soil drenching with fungicides (Two applications)

\begin{tabular}{|c|c|c|c|c|c|c|c|}
\hline \multirow{2}{*}{$\begin{array}{l}\text { Sl. } \\
\text { No. }\end{array}$} & \multirow[b]{2}{*}{ Treatments } & \multicolumn{4}{|c|}{ Fusarial population $\left(\mathrm{cfu} / \mathrm{g}\right.$ of soil $\left.\times 10^{3}\right)$} & \multicolumn{2}{|c|}{ Per cent wilt incidence } \\
\hline & & $\begin{array}{c}\text { Zero day } \\
\text { (Before application) }\end{array}$ & $\begin{array}{l}15^{\text {th }} \text { day after } \\
\text { application }\end{array}$ & $\begin{array}{l}30^{\text {th }} \text { day after } \\
\text { application }\end{array}$ & $\begin{array}{l}45^{\text {th }} \text { day after } \\
\text { application }\end{array}$ & $\begin{array}{c}\text { Before } \\
\text { application }\end{array}$ & $\begin{array}{c}45^{\text {th }} \text { day after } \\
\text { application }\end{array}$ \\
\hline 1. & Propiconazole@0.1\% & 25.60 & 14.00 & 14.30 & 3.00 & $21.50(27.60)^{*}$ & $11.20(19.60)$ \\
\hline 2. & Difenconazole@0.1\% & 23.60 & 17.00 & 11.00 & 8.30 & $15.50(23.10)$ & $11.60(19.90)$ \\
\hline 3. & Carbendazim@0.2\% & 12.60 & 15.00 & 7.30 & 4.60 & $15.50(23.10)$ & $11.60(19.90)$ \\
\hline 4. & Captan@0.2\% & 39.00 & 32.00 & 11.30 & 5.30 & $29.90(33.10)$ & $20.50(26.90)$ \\
\hline 5. & Benomyl @ 0.2\% & 21.60 & 14.60 & 11.60 & 3.60 & $23.50(28.90)$ & $13.00(21.10)$ \\
\hline 6. & Chlorothalonil @ 0.1\% & 23.30 & 19.00 & 11.60 & 3.60 & $28.10(32.00)$ & $21.30(27.50)$ \\
\hline 7. & Untreated check & 25.60 & 25.30 & 27.30 & 26.30 & $27.10(31.40)$ & $28.00(31.90)$ \\
\hline \multicolumn{2}{|c|}{ S.Em \pm} & & 0.84 & 0.78 & 0.61 & 0.44 & 0.63 \\
\hline \multicolumn{2}{|c|}{ CD@ $5 \%$ level } & & 2.59 & 2.41 & 1.89 & 1.37 & 1.94 \\
\hline \multicolumn{2}{|c|}{$\mathrm{CV} \%$} & & 6.06 & 6.94 & 7.87 & 9.81 & 4.88 \\
\hline
\end{tabular}

*Figures in the parenthesis are arc sine transformed values 
Int.J.Curr.Microbiol.App.Sci (2017) 6(10): 2559-2565

Table.3 Management of carnation wilt by soil drenching with fungicides (Three applications)

\begin{tabular}{|c|c|c|c|c|c|c|c|}
\hline \multirow[b]{2}{*}{$\begin{array}{l}\text { Sl. } \\
\text { No. }\end{array}$} & \multirow[b]{2}{*}{ Treatments } & \multicolumn{4}{|c|}{ Fusarial population $\left(\mathrm{cfu} / \mathrm{g}\right.$ of soil $\left.\times 10^{3}\right)$} & \multicolumn{2}{|c|}{ Per cent wilt incidence } \\
\hline & & $\begin{array}{c}\text { Zero day } \\
\text { (Before } \\
\text { application) }\end{array}$ & $\begin{array}{c}15^{\text {th }} \text { day after } \\
\text { application }\end{array}$ & $\begin{array}{c}3^{\text {th }} \text { day after } \\
\text { application }\end{array}$ & $\begin{array}{c}45^{\text {th }} \text { day after } \\
\text { application }\end{array}$ & $\begin{array}{c}\text { Before } \\
\text { application }\end{array}$ & $\begin{array}{c}45^{\text {th }} \text { day after } \\
\text { application }\end{array}$ \\
\hline 1. & Propiconazole @ 0.1\% & 29.80 & 9.30 & 14.30 & 1.60 & $29.80(33.10)^{*}$ & $15.80(23.40)$ \\
\hline 2. & $\begin{array}{l}\text { Difenconazole @ } \\
0.1 \%\end{array}$ & 15.60 & 17.60 & 11.00 & 7.30 & $15.60(23.20)$ & $9.20(17.70)$ \\
\hline 3. & Carbendazim @0.2\% & 22.80 & 43.30 & 7.30 & 2.60 & $22.80(28.50)$ & $12.70(20.90)$ \\
\hline 4. & Captan@0.2\% & 25.30 & 21.60 & 11.30 & 3.60 & $25.30(30.20)$ & $18.60(25.50)$ \\
\hline 5. & Benomyl @ 0.2\% & 23.10 & 14.60 & 11.60 & 7.00 & $23.10(28.70)$ & $15.00(22.80)$ \\
\hline 6. & $\begin{array}{l}\text { Chlorothalonil @ } \\
0.1 \%\end{array}$ & 29.60 & 20.30 & 11.60 & 6.30 & $29.60(32.90)$ & $19.00(25.80)$ \\
\hline 7. & Untreated check & 27.10 & 25.30 & 27.30 & 26.30 & $27.10(31.40)$ & $28.00(31.90)$ \\
\hline \multicolumn{2}{|c|}{ S.Em \pm} & & 0.64 & 0.82 & 0.78 & 0.66 & 0.64 \\
\hline \multicolumn{2}{|c|}{ CD@ $5 \%$ level } & & 1.97 & 2.53 & 2.41 & 2.03 & 1.97 \\
\hline \multicolumn{2}{|c|}{$\mathrm{CV} \%$} & & 4.47 & 6.53 & 6.94 & 14.56 & 4.47 \\
\hline
\end{tabular}

*Figures in the parenthesis are arc sine transformed values 
The fungicide propiconazole was the most important groups of fungicides (Baldwin and Rathmell, 1988). This fungicide showed that the greatest effectiveness in inhibiting Fusarium oxysporum f.sp. cubense growth in vitro as well as suppression of the disease in the green house and they act by inhibiting the demethylation step in the biosynthesis of sterol, which is need in fungal cell walls, they most likely bind to cytochrome P-450 involved in sterol demethylation (Uesugi, 1998). Nel et al., (2007) reported that the fungicides, propiconazole significantly reduced the incidence of Fusarium oxysporum f.sp. cubense with the soil drench treatments 1 week after planting up to 80.6 per cent. Several workers also reported the effectiveness of propiconazole against Fusarium pathogen (Gopinatha et al., 2006; Soad Ahmed and Amar Hemada, 2005).

The wilt incidence in benomyl treated plot reduced to 25.44 to 10.00 per cent in single application of fungicide. The wilt incidence reduced in second and third application of fungicide that is 8 and 4 per cent respectively. Benomyl being a systematic fungicide, acts as a multiplication inhibitor during fungal mitosis (Uesugi, 1998). In the current study, benomyl inhibited the mycelia growth of both Fusarium oxysporum f.sp. dianthi isolates effectively at a high concentration. In the greenhouse trials benomyl was most effective especially as a soil drench for three application. Ram et al., (2004) reported that benomyl was the most effective treatment for the control of corn rot caused by Fusarium oxysporum f.sp. gladioli, followed by carbendazim.

Sunita and Katoch (2001) also reported that, under field conditions carbendazim and benomyl reduced the carnation wilt incidence up to 80 per cent. These results are in line with Fletcher and Martin, (1972) found that soil drenching of benomyl at the rate of $1.5 \mathrm{~g}$ per liter suppressed the symptom expression of fusarium wilt of carnations.

\section{References}

Anonymous, 2004. Horticultural Statistics of Karnataka State At a Glance, 2002-03. Statistical wing, Directorate of Horticulture, Dept of Horticulture, Govt. of Karnataka, Lalbhag, Bangalore. 32pp.

Baldwin, B.C., and Rathmell W G, 1988. Evolution of concepts for chemical control of plant disease. Annu. Rev. Phytopathology26; 265-283.

Fletcher, J.T., and Martin J A, 1972. Spread and control of Fusarium wilt of Carnations. Plant Pathology21: 182187.

Ghosh, M.K., and Sinha A K, 1981. Laboratory evaluation of some systemic fungicides against Fusarium wilt of pigeon pea. Pesticides, 15: 24-27.

Gopinath, K., Radhakrishnan NV and Jayaraj J, 2006. Effect of propiconazole and difenoconazoleon the control of anthracnose of chilli fruits caused by Colletotrichum capsici.Crop Protection25:1024-1031.

Jacob, M., and Krebs B, 1985. Auftren and Bekamfung der Fusarium- Welke bei Edelnelken Nachrichtenblatt furafen pfanzenschutz inder. DDR. 39(1):16-19. [De, ru,en, 12ref., 2fig., 4tab.] Sektion Gartenbau, Hemboldt univ., Berlin, German Democratic republic.

Javed, M.S., Sheikh A W, Idrees M and Saleem A, 1997. Fungi recorded from the onion seeds and control of Fusarium solani by chemicals. Pakistan Journal of Phytopathology9:93-96.

Kapoor, I.J., and Kumar B, 1991. Relative efficacy of systemic and non-systemic fungicides against Fusarium oxysporum and Fusarium solani affecting tomato. Indian Phytopathology44: 87-93. 
Koelsch, M.C., Von Broembsen SL, Cole JC, 1995. Effectiveness of selected fungicides in controlling forliar disease of common periwinkle (Vinca minor L.). Horticulture Sciences30:554-557.

Munkvold, G.P., Dixon PM, Shriver JM and Martinson CA, 2001. Probabilities for profitable fungicide use against grey leaf spot in hybrid maize. Phytopathology91, 477-484.

Nagesh, M., Parvatha Reddy P and Rama N, 2001. Pathogenicity of selected antagonistic soil fungi egg masses under in vitro and in vivo conditions. Journal ofBiological Control15: 63-68.

Narendrappa, T., and Jayarame Gowda B, 1995. Integrated management of Panama wilt of Banana cv. Nanjangud Rasabale. Current Research24: 181183.

Nel, B., Steinbergb C, Labuschagnea $\mathrm{N}$ and Viljoena A, 2007. Evaluation of fungicides and sterilants for potential application in the management of Fusarium wilt of banana. Crop Protectection 26:697-705.

Pratibha Sharma, 2000. An integrated approach for the management of carnation wilt caused by Fusarium oxysporum f. sp. dianthi (Pril. and Del.) Snyd. And Hans. NewBotanist27: 143150.

Ram, R., Manuja S, Dhyani D and Mukherjee 2004. Evaluations of fortified fungicide solutions in managing corm rot disease of gladiolus caused by Fusarium oxysporum. Crop Protection23:783788.

Rathnamma, K., 1994. Studies on root rot of
Garden rue (Ruta graveoleus Linn) caused by Fusarium solani (Mart.) Sacc. Emend snyder and Hansen. M.Sc. (Agri.) Thesis, Uni. Agri. Sci., Bangalore (India).

Shahzad, S., 1994. Studies on soil borne root infecting fungi with special reference to the control of root rot and root knot disease complex. Ph. D Thesis. Dept. Bot., Univ.Karachi, Pakistan. pp. 299.

Smith, B.J., and Black L L, 1991. Greenhouse efficacy of fungicides for control of anthracnose crown rot of strawberry. In: Dale, A., Lubby, J. (Eds.), the Strawberry into the 21st Century. Timber Press, Portland, USA, pp. 221223.

Soad Ahmed, M., and Amal Hemada AH, 2005. Sensitivity of some Fusarium species to fungicides as chemical control for Fusarium diseases. Journal of Pest Control and Environmental Sciences13 (1): 117-131.

Sunita, S.C., and Katoch R, 2001. Chemical control of Fusarium oxysporum f. sp. dianthi, an incitant of carnation wilt. Indian Journal of Microbiology41: 135137.

Tomar, M., 2004. Studies on the management of Fusarium root rot of Acacia catachu Willd. M Sc. Thesis. Dept. Myco. Plant Pathology, India.

Uesugi, Y., 1998. Fungicide classes: chemistry, uses and mode of action. In: Huston, D., Miyamoto, J. (Eds.), Fungicidal Activity-Chemical and Biological Approaches to Plant Protection. Wiley, Chichester, England, pp. 23-56.

\section{How to cite this article:}

Manasa, B.G., Y.M. Somashekara, K. Shankara and Chikkanna Swamy. 2017. Efficacy of Fungicides in Control of Fusarium oxysporum f. sp. dianthi, the Cause of Wilt in Carnation. Int.J.Curr.Microbiol.App.Sci. 6(10): 2559-2565. doi: https://doi.org/10.20546/ijcmas.2017.610.300 